\title{
Individual creativity factor in proactive crisis management in micro and small enterprises
}

Tugay Ulku*, Department of Business Administration, Tokat Gaziosmanpasa Universitesi, FEAS, Gaziosmanpasa Universitesi, Tasliciftlik Yerleskesi, 60250 Tokat, Turkey

Cetin Bektas, Tokat Gaziosmanpasa Universitesi, FEAS, Gaziosmanpasa Universitesi, Tasliciftlik Yerleskesi, 60250 Tokat, Turkey

\section{Suggested Citation:}

Ulku, T. \& Bektas, C. (2021). Individual creativity factor in proactive crisis management in micro and small enterprises. Global Journal of Business, Economics and Management: Current Issues. 11(1), 10-26. https://doi.org/10.18844/gibem.v11i1.4853

Received from December 12, 2020; revised from Febuary 15, 2021; accepted from March 01, 2021.

Selection and peer review under responsibility of Prof. Dr. Cetin Bektas, Gaziosmanpasa University, Turkey. ${ }^{\circ} 2021$ United World Center of Research Innovation and Publication. All rights reserved.

\begin{abstract}
In crisis situations, the survival of businesses depends on the policies which they apply. Businesses that have been able to internalise the concept of crisis management and prepare an environment for their employees that can turn the crisis into an opportunity will be able to survive the crisis moments with the least damage. In this study, it is aimed to determine the effect of individual creativity factor on proactive crisis management, which is necessary for the success of crisis management. Within the scope of the study, the data were collected from 118 participants who were working in micro and small enterprises in Tokat province via questionnaire. $t$-Test, analysis of variance, correlation analysis and simple regression analysis were applied to obtained data. As a result of the analysis, it has been determined that individual creativity and proactive crisis management have a positive relationship $(r=0.505$; Sig. $=0.000)$ and individual creativity positively effects proactive crisis management $\left(R^{2}=0.255 ; p=0.000 ; \beta\right.$ Change $\left.=0.16\right)$.
\end{abstract}

Keywords: Individual creativity, proactive crisis management, micro enterprises, small enterprises. Jel Codes: M1, M10, M19

\footnotetext{
* ADDRESS FOR CORRESPONDENCE: Tugay Ulku, Department of Business Administration, Tokat Gaziosmanpasa Universitesi, FEAS, Gaziosmanpasa Universitesi, Tasliciftlik Yerleskesi, 60250 Tokat, Turkey

E-mail address: tugayulku@gmail.com
} 
Ulku, T. \& Bektas, C. (2021). Individual creativity factor in proactive crisis management in micro and small enterprises. Global Journal of Business, Economics and Management: Current Issues. 11(1), 10-26. https://doi.org/10.18844/gjbem.v11i1.4853

\section{Introduction}

Due to economic, cultural, sociological and technological developments and events, all organisations may face a chaotic environment from time to time (Nizamidou, Vouzas \& Gotzamani, 2019 , p. 541). In this period, which can also be called a crisis, because top management and stakeholders perceive this period as a disruptive and destructive process to achieve the organisation's goals (Bundy, Pfarrer, Short \& Coombs, 2017, p. 1662), organisations try to avoid being behind their competitors and try to evaluate the opportunities created by the crisis environment.

Natural disasters and economic or political crises push businesses out of their current practices and seek new ways to solve problems (Christensen, Lægreid \& Rykkja, 2016, p. 2). For institutions and businesses operating in both public and private sectors, it is possible with an effective crisis management process to be able to get out of the crises with minimal damage and benefit from competitive advantages. Especially in the pre-crisis situation, organisations need to carry out leadership activities regarding crisis preparedness, establish crisis management stages in a way that all employees can understand and develop crisis scenarios (Bowers, Hall \& Srinivasan, 2017, p. 2). Crisis management is not a process that concerns just the top management level of businesses. According to modern approaches (Lockwood, 2005; Vardarlier, 2016), top management has functions such as providing pre-crisis training, forming crisis teams in times of crisis and preparing for the crisis by mentoring their employees (Vardarlier, 2016, pp. 467-468). All personnel working within the organisation should have internalised the crisis management approach and be ready to implement. Otherwise, the processes and procedures planned within the scope of crisis management remain only on paper and cannot be applied throughout the organisation.

The ability of organisations to manage crisis successfully is directly related to their innovative and creative climate because in crisis times, standard practices and procedures will not be effective and efficient. As mentioned above, the process of revealing innovative and creative views will be possible with the contribution of all staff working in the organisation. In this period, it will be possible for organisations to act innovatively and to direct the environment in this direction, thanks to the creativity of the management and employees (Ivanus \& Repanovici, 2016, p. 157). At this point, creative approaches of individuals should be taken into consideration by the top management, especially during the time period before the crisis, when the signals are perceived and during the crisis preparation stages. Otherwise, if the creativity of individuals is tried to be reduced due to environmental conditions, management pressure or various obstacles (crises etc.) and innovation decreases parallel to this (Ma \& Jiang, 2018, p. 3).

The vast majority of organisations in the world consist of micro, small and medium-sized enterprises, and in the same way, the vast majority of them are family-owned enterprises that have family members on their boards (also see OECD statistics). These types of businesses suffer more from crisis due to the lack of a large capital infrastructure, low level of institutionalisation compared to large businesses and lack of self-reliance (Mikusova \& Horvathova, 2019, p. 1844). Because of these disadvantages, micro and small businesses are required to engage in value-added activities, especially in crisis times (Widera, Fonio, Lechtenberg \& Hellingrath, 2018). To do this, individual creativity needs to be transformed into organisational innovation. This will be possible in a climate where creativity is supported by the organisation. Otherwise, innovation initiatives without creativity will not yield results that are interesting, value-added and detracting from the negative effects of the crisis in the sector (Dorcas, 2017, p. 21). Micro and small enterprises are structures that form the basis of the economy. A more detailed analysis of these structures will enable a better analysis of the economic developments of the countries. In this context, the main purpose of the study is to determine individual creativity levels of the employees in micro and small enterprises and to determine whether the individual creativity levels of the employees have an impact on their perceptions of proactive crisis management. In this way, decisions in micro and small enterprises should not only be taken by top management, but also by employees' participation in management which will increase effectiveness and efficiency, and thus proactive crisis management will be successful. It is aimed to contribute to the 
Ulku, T. \& Bektas, C. (2021). Individual creativity factor in proactive crisis management in micro and small enterprises. Global Journal of Business, Economics and Management: Current Issues. 11(1), 10-26. https://doi.org/10.18844/gjbem.v11i1.4853

literature on the idea of preventing crises before they arise, at least to minimise the negative effects created by crises.

\section{2. Review of literature}

\subsection{Crisis management}

In order for organisations to successfully manage crisis, the concept of crisis must be understood well. The crisis is the 'moment of decision' that will make a decisive difference for the worse or better, in an unstable or crucial timeframe (Danielsson \& Sjostedt-Landen, 2020, p. 142; Devlin, 2007, p. 4). As it is seen, the crisis may be a threat or it is perceived as an opportunity in terms of its results. The words of former American President Kennedy $(1959,1960)$ on this matter are quite meaningful:

"In Chinese writing, the word "crisis" is a combination of two characters: one character represents danger and the other character represents opportunity".

In another definition, the crisis, in the event of great danger or difficulty, when uncertainty prevails, is the moment when everything in the current order is transformed (Ansell \& Boin, 2019, p. 1081; Sui Pheng, Ho \& Soon Ann, 1999). In another related definition, crisis is expressed as processes that can disrupt organisational activities, make management difficult and create conflicts within the organisation (Tagraf \& Arslan, 2003). Based on the definitions of the concept of crisis, it is stated that crises can occur in unexpected moments and the results cannot be foreseen. Therefore, the crisis is a situation that every organisation can encounters. Organisations emerging from crises stronger or weaker are related to planned activities, namely crisis management (Sui Pheng et al., 1999, p. 231). Crises can help organisations improve themselves by providing new perspectives that they cannot achieve at normal times (Roux-Dufort, 2007, p. 106). As a strategic activity, it is possible for organisations to turn crises into opportunities, thanks to crisis management that will be carried out primarily under the responsibility of top management.

In order to create an effective crisis management in terms of organisations, the causes, characteristics and magnitudes of the emerging crises should be analysed well. Crises can occur within or outside the organisation. Natural disasters, political changes, technological developments etc. are crises that occur outside the control of organisations and constitute external environmental factors. Crises that arise due to structural problems in the organisation are internal environmental factors (Tugcu, 2004, p. 17).

\subsubsection{Variables of crisis management}

There are broadly two different typologies in the crisis management literature: the approach that sees the crisis as an event and the approach that sees the crisis as a process (Williams, Gruber, Sutcliffe, Shepherd \& Zhao, 2017). Compared to the event approach, which sees the crisis as an event and tries to understand the post-crisis situation, the process approach analyses the stages of the crisis and makes assumptions on what organisations can do according to these stages (Roux-Dufort, 2016; Williams et al., 2017). Since crises can occur at an unexpected time, there are issues that business executives should pay attention to regarding the potential crisis expectation. The organisation's top management and all other employees' familiarity with the concepts of crisis and crisis management will contribute to less damage to the resources of the organisation during the crisis and can be a preparation for subsequent crises. Pearson and Mitroff (1993, p. 50) explained the four-variable crisis management approach which belongs to process approaches that emerged in companies with a crisis management concept as a result of their long-term research. These variables are crisis types, crisis stages, systems and stakeholders, respectively.

\subsubsection{Classification of crisis types}

The fact that organisations have different applications related to crisis management arises from the emergence of different types of crises. In addition, it is observed that employees also create crisis 
types through shortcuts and act accordingly. In doing so, they benefit from their intuition and past experiences (Bundy et al., 2017). That is why each crisis that occurs has an effect on the organisation's perspective on crisis management, its practices and measures that can be taken for subsequent crises. To this end, the sources of crisis were divided into six categories by Pearson and Mitroff (1993) and Sui Pheng et al. (1999) as follows:

- External crisis: This type of crisis directly effects the economic and financial situation of the organisation, e.g. corruption, bribery, boycott, extortion, economic fluctuations etc.

- External information attacks: In such crises, confidential information about the organisation is leaked out, e.g. stealing confidential information, spreading damaging rumours etc.

- Physical crises: Crises that occur in the buildings, security systems or equipment owned by the business. Natural disasters are crises included in this group.

- Psychopathological crises: Crises that occur as a result of criminal activities within the organisation, e.g. sexual harassment, unauthorised changes in products, sabotage etc.

- Human resources-based crises:iThese are the crises that occur with the decline in the morale and motivation of the individuals working in the organisation.

- Crises for Organisation Reputation: These are the crises that shake the organisation's reputation, e.g. employees making statements in favour of competitors, hacking websites etc.

There are different classifications of crises in the literature. Coombs (2007) distinguished crises between internal and external crises and Ritchie (2004) differentiated crises between internal factors and external factors resulting from organisational structure (Oran \& Demir, 2016). In another classification, Parsons (1996) divided crises into three categories: acute crises, visible crises and longterm crises. As in most theories, it is natural for classifications to differ in the field of crisis management. The important point here is whether organisations carry out their crisis management processes in accordance with the classification they have determined.

\subsubsection{Crisis stages}

Undoubtedly, the crises that occur have a beginning and an end. The important point is that managers are informed about the stages of the crisis. If managers are aware of the crisis stages, they will be able to correctly direct other employees with regard to the procedures and measures to be taken. The stages of a crisis are shown in Figure 1.

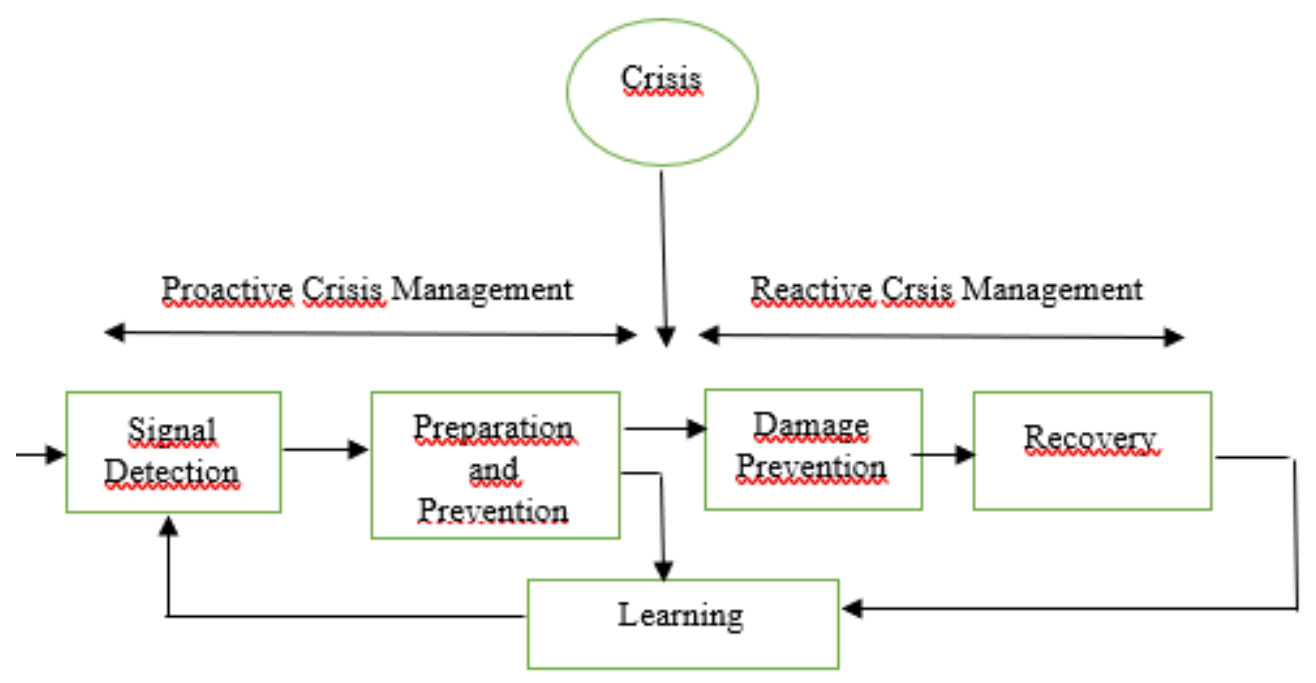

Figure 1. Stages of crisis. Source: Tagraf and Arslan (2003)

As seen in Figure 1, business management practices do not only consist of the applications that occur during or after the crisis. Crisis management also covers pre-crisis practices. Another name for 
crisis management before the crisis is 'proactive crisis management'. The signal detection phase, which is the first phase of the crisis, acts as a kind of an early warning system. At the signal detection stage, managers take the first steps towards a possible crisis and motivate other employees in this direction (Tekin, 2016, pp. 125-126). The second phase, preparation and prevention, includes strategic action plans for potential crises. At this stage, all employees in the organisation receive training on what to do in case of a possible crisis (Soysal, Karasoy \& Alici, 2009, pp. 436-437). The third stage is the damage prevention stage. At this stage, the effects of the damage caused by the crisis are tried to be reduced. Managers exchange ideas with stakeholders at the point of preventing damage and ensure that the production of goods and services is maintained at the desired level. The fourth and final stage is the recovery stage. In the last stage, the organisation aims to return to standard practices with long- and short-term moves (Hutchins \& Wang, 2008, p. 318).

\subsubsection{Organisation systems}

Organisations should be aware of the resource capacities under the following five headings in order to have an effective crisis management:

- Technical Features: The equipment that enables organisations to move in line with the intended targets (Pearson \& Mitroff, 1993).

- Human Resources Features: It represents the workforce that can work effectively and efficiently under stress (Liu, Gong, Zhou \& Huang, 2017).

- Structural Features: It represents the existence of cooperation and coordination among the employees on issues such as which communication channels will be used in the organisation during the crisis and who is responsible for crisis management (Hyvarinen \& Vos, 2015; Johansson \& Back, 2017).

- Cultural features: It performs to have an organisational culture that will create a positive atmosphere within the organisation during the times of crisis (Chen \& Hou, 2016).

- Emotion/belief features: For an effective crisis management, first of all, it is necessary to convince the employees that the crisis management will be successfully completed by starting from the top management. At this point, an emotionally harmonious structure should be established at the basis of the organisation (Pearson \& Mitroff, 1993).

\subsubsection{Stakeholders}

The stakeholders of the organisation, as well as the organisation, are affected positively or negatively from the crisis environment since the stakeholder environment (individual customers, other companies, interest groups, media, political organisations, non-governmental organisations etc.) owned by the organisations during the crisis periods will have different demands from each other. In this period, the crisis can reduce the reputation of the organisation, upset the stakeholders and increase the pressure on top management (Vardarlier, 2016, p. 463). The organisations must create a crisis management plan considering the demands of each stakeholder group (Sui Pheng et al., 1999, p. 236).

\subsubsection{Crisis process and proactive crisis management}

In short, crisis management is a process in which all stakeholders are involved and strategic steps are taken by top management towards the crisis (Martens, Feldesz \& Merten, 2016, p. 91; Ponis \& Ntalla, 2016, p. 669). It is possible for organisations to carry out crisis management effectively by taking measures regarding a potential crisis. Organisations operating in both public and private sectors are trying to eliminate the devastating effect of the crisis by obtaining some signals in the crisis environment (Ritchie, 2004, p. 674). For an organisation that is ready to adapt to environmental change, it is possible to be protected from the side effects of the crisis from the first stage to the last stage. At this point, the concept of 'proactive crisis management' comes into play. Proactive crisis management consists of a series of activities covering pre-crisis management stages (Wobodo \& Oparanma, 2019, p. 10). 
Proactive crisis management starts with the activation of the management level in light of the signals coming from within or outside the organisation before the crisis (Mitroff, 2019, p. 89). By sharing the incoming signals with the organisation, the top management implements activities such as using resources effectively and efficiently, creating crisis management plans, realising crisis scenarios etc. (Soysal et al., 2009, p. 436). The purpose of proactive crisis management is primarily to ensure that strategic planning is at the target, to prevent the inefficient use of resources, to reduce the level of risk, to save time (Ritchie, 2003, p. 674) and to fulfil the wishes of stakeholders (Alpaslan, Green \& Mitroff, 2009, p. 40).

In proactive crisis management, the management level starts working on the early signals perceived by the departments within the organisation. At this stage, the more accurately the crisis management process is managed, the negative effects of potential crises can be reduced and even organisations can come out of the crisis with more power (Kash \& Darling, 1998, p. 182) For this, organisations need to establish crisis teams, ensure correct communication during the crisis and train their employees about the crisis (Hutchins \& Wang, 2008, pp. 316-317). According to Tagraf and Arslan (2003, pp. 153-158), businesses should also provide and have features such as accurate and sufficient information flow, identify risk amount to consider, establish early warning systems, prevent crisis prevention planning, put plans into writing, amount of sacrifice, identification and creating crisis prevention teams to determine proactive crisis management. In another classification, Kash and Darling (1998, pp. 182183) gathered the qualities that proactive crisis management should have in four different groups: strategic forecasting, emergency planning, problem analysis and scenario analysis. All the abovementioned techniques are the techniques that managers need to master in proactive crisis management. Thanks to the use of these techniques, rather than a management approach that tries to solve the problems that arise constantly, a management approach that can predict problems will save time and resources, the future crisis management approach will spread throughout the organisation, training and personnel selection will improve and competitive advantage will be achieved (Ritchie, 2003, p. 675).

\subsection{Individual creativity}

In order to clarify more clearly what the concept of individual creativity means for the organisation, it is useful to define the concept of creativity first. Creativity is simply used to create a new, appropriate, original and effective solution (Simonton, 2018) for a task whose outcome is unknown, to design a new product and to find new answers (Amabile, 2012, p. 2). In order for the developed solutions or ideas to be considered creative, they must not only be different but must also be new. Also, the developed solutions must be fit for the purpose, i.e. the ideas developed must be valuable, solution-oriented and feasible (Amabile, 2012, p. 2).

Based on the definition, it is seen that individual creativity and organisational innovation are different. While organisational innovation is the process of developing and implementing thoughts throughout the organisation, new useful ideas and solutions in individual creativity are produced by individuals (Bogilovic, Cerne \& Skerlavaj, 2017; Dong, Bartol, Zhang \& Li, 2017). Thus, individual creativity forms the basis of organisational innovation (Zhou, 2003, p. 413). Thanks to the development of individual creativity, solutions are produced for businesses, business processes can be changed and new steps can be taken strategically (Zhou \& Shalley, 2003, p. 167).

\subsubsection{Factors of individual creativity}

Formation processes of individual creativity are studied by researchers from different perspectives. The first attempts to identify the determinants of individual creativity were carried out by Amabile (1988) (Zhou \& Shalley, 2003, p. 166). Amabile (1988), who looks at individual creativity as a psychological phenomenon, carried out an experimental study by proposing a model for the effect of personal and environmental factors on individual creativity. On the other hand, Shalley (1991) explained that individual creativity can be shaped in line with the goals of productivity and creativity. 
In terms of individual creativity, which is handled sociologically as well as with psychological approaches, Ford (1996) explained the effects of environmental factors on individual creativity from a macro perspective (Pirola-Merlo \& Mann, 2004, p. 236).

Many studies have been conducted on the formation of individual creativity through organisational structure and individual differences (Amabile \& Pratt, 2016; Amabile, 1996; Bourgeois-Bougrine, Buisine, Vandendriessche, Glaveanu \& Lubart, 2017; Chang, Lin, Chien and Yen, 2018; Eisenberger \& Selbst, 1994; Oldham \& Cummings, 1996; Shalley \& Oldham, 1997; Tierney \& Farmer, 2002; Verma \& Rao, 2016; Zhou \& George, 2001). In the aforementioned studies, it is seen that intelligence and motivation to be innovative and creative features come to the fore in the formation of individual innovation (Bharadwaj \& Menon 2000, p. 425).

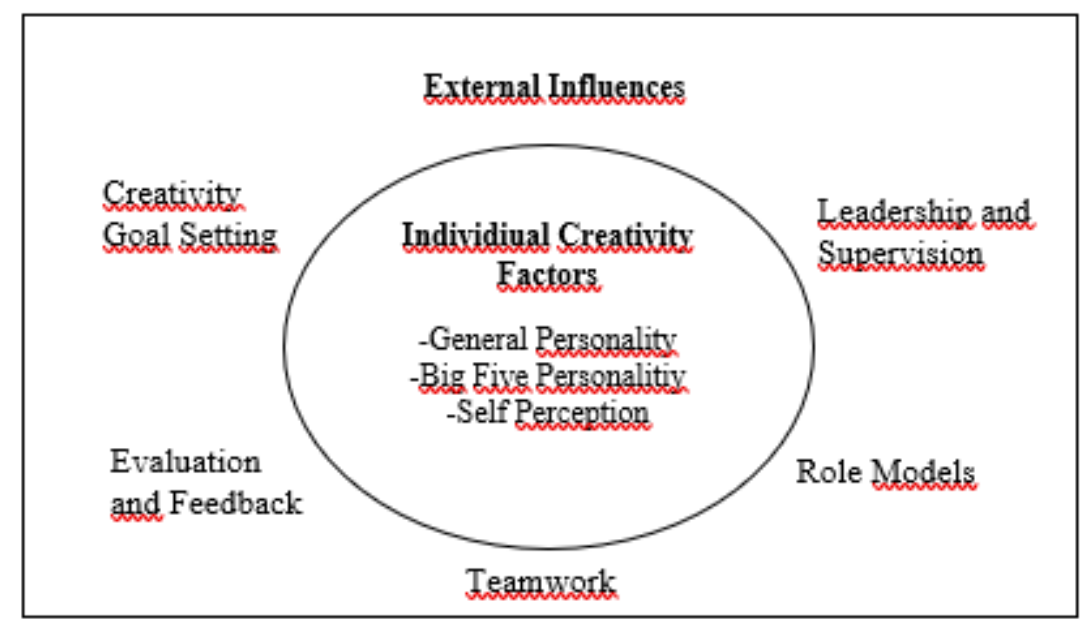

Figure 2. Individual creativity components. Source: Egan (2005)

As can be seen in Figure 2, Egan (2005, p. 164) examined 121 peer-reviewed articles and, as a result, compiled the studies on individual creativity and schematised the factors that make up individual creativity.

The first of the basic works explaining individual creativity is 'The Componential Theory of Creativity', which is developed by Amabile (1988) (Pirola-Merlo \& Mann, 2004, p. 236). Amabile (2012, p. 2) explains that in her theory that individual creativity consists of three components. According to the theory, high creativity in individuals depends on wisdom, creativity-oriented skills and motivation. Individual creativity emerges when high internal motivation, wisdom, expertise, technical ability and creativity skills in individuals are encouraged. In the following years, Amabile and Pratt (2016) developed the theory and listed the factors that constitute individual creativity as follows: intrinsic motivation, creativity-relevant processes and skills in the task domain.

Similar to Amabile's (1988) theory, Ford (1996) proposed a model that tries to explain individual creativity. Ford's (1996) model also has a three-component structure. These are intuition, motivation and wisdom and ability. In this theory, it is stated that individuals exhibit creative and habitual behaviours from time to time according to behavioural segmentation, and that creative behaviours can be demonstrated by skilled individuals in situations where intuition and motivation are high (Pirola-Merlo \& Mann, 2004, pp. 236-237). Finally, another theoretical study on the factors that form individual creativity was carried out by West (1990). West (1990) argues that creativity can only be possible through innovation-oriented team work. According to the theory, team members who share the same vision can produce creative thoughts for a common purpose if they can express their thoughts fearlessly and have an atmosphere that supports being innovative and creative (Pirola-Merlo \& Mann, 2004, p. 237). 


\subsubsection{Characteristics of creative individuals}

There are cognitive, psychological or sociological differences between individuals who are individually creative and those who are not. In the emergence of individual creativity, concepts such as interests, behaviours and motivation are at the forefront rather than reasons such as age, gender and educational status (Dellas \& Gaier, 1970). As a result of the studies carried out, people who are creative in the individual sense have features like skilled, proactive personality (Li et al., 2017), egoistic, intelligent, individual, cunning, original, self-confident, tolerance for ambiguity, openness to experience (Guo, Su \& Zhang, 2017), sexy and have a sense of humour (Egan, 2005).

Creative individuals are individuals who trust themselves more than non-creative individuals. On the other hand, it was determined that individuals who could not be described as creative have less experience, less trust in themselves and less self-respect. Individuals in this situation, rather than being creative in an individual sense, adopt an introverted work style (Guo et al., 2017) and work on the role models they choose for themselves; so they tend to repeat the behaviours they see from the role models and move away from creativity (Zhou, 2003).

Cengiz, Acuner and Baki (2007) classified the characteristics of creative individuals as follows:

- People who can construct many thoughts at the same time and form the conceptual relationship between them;

- Motivated for the solution of problems and creating original ideas by producing tasks that have not been tried before;

- People who do not adopt a subordinate-parent relationship, carry out detailed analyses and reveal themselves in order to reveal creative ideas when they feel free are considered as creative individuals (Cengiz et al., 2007).

\subsection{The relationship between individual creativity and proactive crisis management}

It is pre-tested that crisis management cannot be successful without creativity for organisations that face any crisis, as there are no organisations that are not effected by any crisis. In cases of uncertainty and inability to see the future, it is not possible to get out of the crisis by getting stronger when the methods which were previously tried are applied in the same way. Creative thinking is one of the first stages of crisis management in this sense (Pearson \& Sommer, 2011).

In order for proactive crisis management to achieve its goal, organisations need to create a space that encourages creative thinking and can perform impromptu actions for their employees, because impromptu behaviour is a social activity that means going out of routine in unexpected moments, to survive and prosper for organisations (Rhee \& Choi, 2017) and doing what was not thought of before (Webb \& Chevreau, 2006). Individual creativity is an improvisation activity (Webb \& Chevreau, 2006) that enables the emergence of new ideas or products that others have not previously thought of (Wooten \& James, 2008).

It is possible for organisations to emerge from crisis environments with minimal damage or strength by creating an environment suitable for improvised behaviours with a flexible management structure. In an organisation managed within the framework of strict rules, individuals will not feel comfortable and creative thoughts will not emerge. It is observed that creating a flexible working environment for employees by increasing happiness in organisations increases creativity, because in such an environment, employees can find the opportunity to bring together different cognitive processes (Ribeiro, Duarte, Filipe \& Torres de Oliveira, 2020). Employees who feel happy, peaceful and participatory in decisions within the organisation will increase their commitment to the organisation and this will enable them to be more creative (Montani, Courcy \& Vandenberghe, 2017; Semedo, Coelho \& Ribeiro, 2016). All these reasons show that organisations should adopt an appropriate management approach, taking into account the relationship between crisis management and creativity. Otherwise, early warning systems for crisis signals will not work efficiently and proactive crisis management will not be used effectively (Webb \& Chevreau, 2006). 
Wooten and James (2008) stated that creativity has an important effect on the prevention and preparation stages of crisis management. The prevention and preparation phase is also part of proactive crisis management. In order for creativity to give desired results in proactive crisis management, organisations must have policies for producing, implementing and thinking about creative ideas (Lundvall, 2008). In short, long-term procedures should be implemented in proactive crisis management, where individual creativity is encouraged and employees should be adopted. Otherwise, employees may experience a lack of motivation to produce creative thinking when needed. This prevents the emergence of different creative thoughts in times of crisis and causes the possibility of getting out of the crisis by disappearing (Brockner \& James, 2008).

In contrast to generally accepted thought, the existence of time pressure is not a situation that increases creativity. On the contrary, time pressure reduces creativity (Pearson \& Sommer, 2011). In addition, some studies found that restrictions on certain subjects increase creativity (Brooks, Curnin, Owen \& Boldeman, 2019; Rosso, 2014). In this context, when considering the relationship between proactive crisis management and creativity, it should be remembered that proactive crisis management is a management approach applied before the crisis occurs. Therefore, it is assumed that there is no time pressure on the employees during the proactive crisis management process. In times of crisis, the practices carried out to eliminate the effects of the crisis are reflected on to the employees with time pressure, because after the crisis occurs, it is felt necessary to eliminate the negative situations as soon as possible within the organisations. In line with this entire theoretical framework, the hypothesis of the research is formed as follows:

$\boldsymbol{H}_{1}$ : Individual creativity of employees positively effects their perception of proactive crisis management.

In the following sections of the study, information will be given about the study conducted to determine whether the hypothesis put forward within the scope of the main problem of the research is supported or not.

\section{Methods}

The study was prepared as an explanatory research and as an applied and application type (Saruhan \& Ozdemirci, 2018) in order to determine the interaction between individual creativity level and proactive crisis management perception. The main problem of the study is to determine which individual factors depend on the ability of micro and small enterprises to carry out crisis management successfully. After the related literature was scanned, individual creativity was analysed as an independent variable and proactive crisis management as a dependent variable.

The research model is shown in Figure 3.

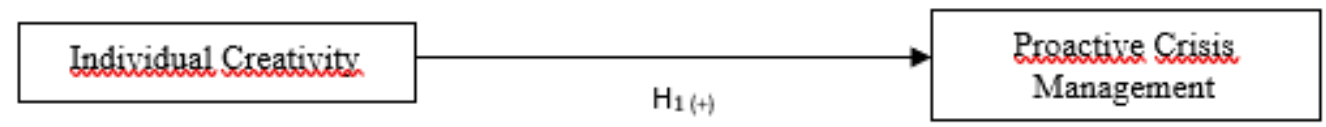

Figure 3. Research model

According to the 2018 data, the population of the study comprise 1,680 employees working within 376 micro and small enterprises operating in Tokat province. The reason why the research population consists of employees in micro and small businesses is because these enterprises have a lessdeveloped institutional structure compared to large enterprises, and therefore, employees are less likely to participate in decision-making mechanisms. Surveys were sent to 150 employees who were targeted with convenience sampling as a sampling method, but only 118 were returned. The sample of 118 employees worked in the food, textile and manufacturing sectors.

In the scope of the study, a questionnaire was used as a data collection method. The questionnaire was created by combining the 'pre-crisis period' sub-dimension of the crisis management scale used in 
the work of Aksu and Deveci (2009) with the individual creativity dimension of the scale developed by Balay (2010). The created questionnaire consisted of 23 items in total. The questionnaire was rated on a 5-point Likert-type scale. Participants were asked to mark the most appropriate one among 'Strongly Disagree' and 'Strongly Agree'.

In light of the data obtained, firstly, information about demographic variables was given within the scope of the study. Then, the validity and reliability analyse of the scale was carried out, respectively. Independent samples $t$-test and analysis of variance (ANOVA) were used to determine whether demographic variables had statistically significant differences in terms of research variables. In addition, correlation analysis was used to determine whether there is a relationship between individual creativity and proactive crisis management variables, and regression analysis was used to measure the interaction between individual creativity and proactive crisis management.

\section{Findings and discussion}

\subsection{Reliability and validity analysis}

In order to determine the statistical accurate measurement of the scale used in the research, reliability analysis was carried out (Table 1 ).

Table 1. Reliability analysis of the scale

\begin{tabular}{|l|l|l|}
\hline $\begin{array}{l}\text { Cronbach } \\
\text { Alpha }\end{array}$ & $\begin{array}{l}\text { Standardized } \\
\text { Cronbach Alpha }\end{array}$ & N \\
\hline, 928 &, 929 & 23 \\
\hline
\end{tabular}

The reliability coefficient of the whole scale was determined to be 0.928 . The scale is considered to be reliable since the relevant coefficient is over 0.70 , which is accepted in social sciences. In addition, the reliability coefficient of the items belonging to the individual creativity variable was determined as 0.909 , and the reliability coefficient of the items regarding the proactive crisis management was 0.888 .

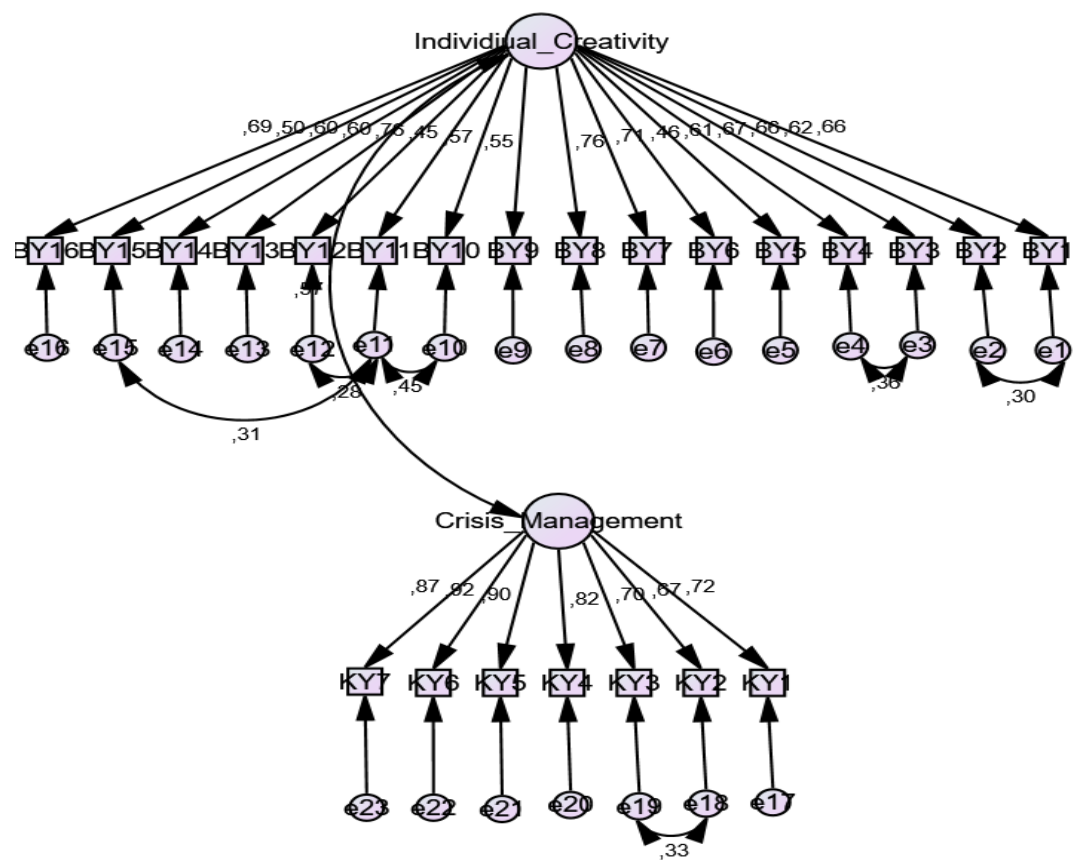

Figure 4. Confirmatory factor nalysis 
The model formed as a result of the confirmatory factor analysis carried out for the scales used in the study is shown in Figure 4. As a result of the confirmatory factor analysis, covariance and error margins were combined among some items of individual creativity and proactive crisis management variables. After all the improvements for the model have been made, the values obtained are as follows: CMIN/df: 1.527; GFI: 0.815; NFI: 0.805; CFI: 0.921 and RMSEA: 0.067. These values provide the values accepted in the literature. Therefore, the scales are considered valid. In the standardised factor loads obtained as a result of confirmatory factor analysis, it was determined that the factor load of each item was higher than 0.45. In addition, both variables were considered statistically valid according to the results of the explanatory factor analysis applied to both individual creativity and proactive crisis management expressions in a single dimension (individual creativity's KMO and Bartlett's test: $0.883 ; p$ : 0.000; proactive crisis management's KMO and Bartlett's test: 0.916; $p$ : 0.000 ). As a result of the explanatory factor analysis for both variables, it was observed that the factor loads of the items were over 0.50. Within the scope of the research, both confirmatory and explanatory factor analyses were carried out on the expressions of the variables. As a result of both analyses, the scales are considered valid and reliable.

\subsection{Normality test}

In order to analyse the data with parametric tests, the data should show normal distribution. As a result of the normality distribution analysis, the kurtosis and skewness values of the individual creativity variable were determined as -1.475 and 2.085 , respectively, and the kurtosis and skewness values of the proactive crisis management variable were -0.803 and -0.319 , respectively. George (2011) states that the skewness and kurtosis values between +2 and -2 indicate that the data are normally distributed. As a result of the analysis, the skewness and kurtosis values of the scales used in the research are considered to provide normal distribution. Based on the assumption that it is normally distributed, it is possible to carry out parametric tests for variables.

\subsection{Independent samples t-test and ANOVA}

In the $t$-test results for the analysis of demographic data, no statistically significant difference was found between both individual creativity and proactive crisis management scores of gender and marital status groups. Similarly, in ANOVA, which was carried out for the comparison of multiple groups, no statistically significant difference was found in terms of the average of individual intelligence and proactive crisis management scores for variables of age, graduation status, working time and income status.

\subsection{Correlation analysis}

Correlation analysis was carried out in order to understand whether there is a relationship between variables or whether variables act jointly is shown in Table 2.

Table 2. Correlation analysis of individual creativity and proactive crisis management

\begin{tabular}{|lc|c|c|}
\hline & & $\begin{array}{c}\text { Individual } \\
\text { Creativity }\end{array}$ & $\begin{array}{c}\text { Proactive Crisis } \\
\text { Management }\end{array}$ \\
\hline Individual Creativity & Pearson Correlation & 1 &, $505^{* *}$ \\
& Sig. (2-tailed) & &, 000 \\
& $\mathrm{~N}$ & 118 & 118 \\
\hline Proactive Crisis Management & Pearson Correlation &, $505^{* *}$ & 1 \\
& Sig. (2-tailed) &, 000 & 118 \\
& $\mathrm{~N}$ & 118 & 118 \\
\hline
\end{tabular}


When Table 2 is analysed, it is seen that individual creativity and proactive crisis management have a positive and moderately linear relationship ( $r=0.505)$ (Altunisik, Coskun, Bayraktaroglu \& Yildirim, 2010 , pp. 227-228) in the $99 \%$ confidence interval (Sig. $=0.000$ ). As a result of this analysis, depending on the study sample, it is accepted that the level of individual intelligence and proactive crisis management perception act jointly.

\subsection{Regression analysis}

With the simple linear regression analysis conducted to test the hypothesis of the research, it was determined whether individual creativity affected proactive crisis management.

Table 3. Summary of individual creativity-proactive crisis management regression model

\begin{tabular}{|c|c|c|c|c|}
\hline Model & $\mathbf{R}$ & $\mathbf{R}^{2}$ & Adjusted $\mathbf{R}^{2}$ & $\begin{array}{c}\text { Std. Error of } \\
\text { Estimate }\end{array}$ \\
\hline 1 &, $505^{2}$ &, 225 &, 248 &, 86630 \\
\hline
\end{tabular}

andependent variable, individual creativity.

When the regression analysis results are analysed (Table 3 ), it is seen that individual creativity has statistically significant effects on proactive crisis management. Accordingly, approximately $25 \%$ of the proactive crisis management perception can be explained by individual creativity $\left(R^{2}=0.255\right)$.

Table 4. ANOVA ${ }^{a}$

\begin{tabular}{|cl|c|c|c|c|c|}
\hline & Model & Sum of Sguares & df & Mean Sguare & F & Sig. \\
\hline 1 & Regression & 29,733 & 1 & 29,733 & & \\
& Residual & 87,055 & 116 &, 750 & 39,620 &, $000^{b}$ \\
& Total & 116,788 & 117 &, 758 & \\
\hline
\end{tabular}

${ }^{a}$ Dependent variable, proactive crisis management, $\mathrm{b}$ : Independent variable, individual creativity.

When Table 4 is examined, it is seen that $p$-value is 0.000 . This proves that the interaction between individual creativity and proactive crisis management is meaningful.

Table 5. Results of individual creativity-proactive crisis management regression analysis

\begin{tabular}{|c|c|c|c|c|c|}
\hline Jariable & $\underline{\underline{\beta}}$ & Std. Error & $\begin{array}{c}\text { Standardized } \\
\text { Coefficients }\end{array}$ & $\underline{\underline{\mathbf{t}}}$ & $\mathbf{S i g .}$ \\
\hline Individual Creativity &, 777 &, 123 & & 1,201 &, 232 \\
\hline Broactive Crisis Management &, 617 &, 514 &, 505 & 6,294 &, 000 \\
\hline
\end{tabular}

andependent variable, individual creativity.

Finally, when proactive crisis management is considered constant, i.e. it has no relationship and interaction with individual creativity, it rises to 0.777 level when it is 0.617 , due to the change of individual creativity level (Table 5). When all findings are evaluated jointly, the following hypothesis is supported:

$\boldsymbol{H}_{1}$ : Individual creativity of employees positively effects their perception of proactive crisis management.

\section{Conclusion and recommendations}

It is thought that the relationship and interaction of behaviour characteristics such as creativity, innovation and ethical behaviour with crisis management should be examined in more detail than physical activities required for the solution of problems encountered in crisis situations.

It will be possible for both managers and employees to respond to the developments in the fastest way in crisis situations by placing a suitable structure within the organisation. It is thought that a structure that motivates individual creativity will increase the capacity of employees to take early action during the times of crisis. Creating this structure is related to the awareness of managers and 
leaders on crisis management and motivation. When the results are analysed, it is seen that individual creativity positively affects proactive crisis management. These results are especially important for micro and small businesses. It is believed that businesses that prepare an environment for their employees to be creative can better manage crisis management.

Micro and small enterprises are heavily affected by crises, because in these enterprises the capital reservoir is narrow, the level of institutionalisation is low and professional relationships between managers and employees are weak. The fact that employees know the requirements of crisis management under these conditions does not mean that they will be successful in crisis management. However, as Lundvall (2008) emphasises, the creativity of family businesses and small business employees, those who seem ordinary workers in general, is one of the important elements of success in crisis management. The involvement of employees in management decisions will help eliminate different types of threats by paving the way for the emergence of different ideas and practices.

In addition, crises should not be considered as a negative factor. One of the most valuable resources of organisations is 'Human Capital'. Organisations should have a structure that can turn crises into opportunities, thanks to this unique resource that they have. It is believed that the society needs it more than ever before, which can survive the crisis and continue to produce goods and services. The work of Webb and Chevreau (2006) supports this idea. Therefore, it is thought that it will be beneficial to create an organisational climate that benefits from and even encourages positive competition among employees. Also, according to Parjanen (2012), the support of management is needed to reveal the creativity of employees. In addition, creativity in the individual sense should not only be seen as a responsibility of the R\&D department, but creativity should be encouraged as a process that covers the entire organisation.

The data analysed in the research are the statistical reflections of the participants' instant feelings and thoughts. Therefore, it would not be correct to generalise the results obtained in the study for all micro and small enterprises' employees. In order to examine the interaction between individual creativity and proactive crisis management in more detail, it is thought that conducting a qualitative study by meeting face-to-face with the employees will yield more comprehensive results.

It is the preliminary acceptance that the markings of the employees in the survey form are made with a rational approach. If the same study is repeated on different dates, there is a possibility that different results will occur. It is accepted that the findings obtained as a result of the research are valid for the period and sample of the study.

In the upcoming period, it is very important to conduct studies on the interaction between individual or organisational creativity and other stages of crisis management. The crisis process should be well analysed from start to finish and employees' creativity should be ensured. In parallel, it is suggested to other researchers to examine the interaction of creativity and crisis management under the mediator effects of the organisational climate and to look at the moderator effects of motivation factors that increase creativity. Thus, important contributions to the literature will be made.

\section{References}

Alpaslan, C. M., Green, S. E. \& Mitroff, I. I. (2009). Corporate governance in the context of crises: towards a stakeholder theory of crisis management. Journal of Contingencies and Crisis Management, 17(1), 38-49.

Altunisik, R., Coskun, R., Bayraktaroglu, S. \& Yildirim, E. (2010). Sosyal bilimlerde arastirma yontemleri: SPSS uygulamali. Sakarya yayincilik.

Amabile, T. M. (1988). A model of creativity and innovation in organizations. Research in Organizational Behavior, 10(1), 123-167.

Amabile, T. M. (1996). Creativity in context. Boulder, CO: Westview Press

Amabile, T. M. (2012). Componential theory of creativity. Harvard Business School, 12(96), 1-10. 
Ulku, T. \& Bektas, C. (2021). Individual creativity factor in proactive crisis management in micro and small enterprises. Global Journal of Business, Economics and Management: Current Issues. 11(1), 10-26. https://doi.org/10.18844/gjbem.v11i1.4853

Amabile, T. M. \& Pratt, M. G. (2016). The dynamic componential model of creativity and innovation in organizations: making progress, making meaning. Research in Organizational Behavior, 36, 157-183.

Ansell, C. \& Boin, A. (2019). Taming deep uncertainty: the potential of pragmatist principles for understanding and improving strategic crisis management. Administration and Society, 51(7), 1079-1112.

Bharadwaj, S. \& Menon, A. (2000). Making innovation happen in organizations: individual creativity mechanisms, organizational creativity mechanisms or both? Journal of Product Innovation Management: An International Publication of the Product Development and Management Association, 17(6), 424-434.

Bogilovic, S., Cerne, M. \& Skerlavaj, M. (2017). Hiding behind a mask? Cultural intelligence, knowledge hiding, and individual and team creativity. European Journal of Work and Organizational Psychology, 26(5), 710723.

Bourgeois-Bougrine, S., Buisine, S., Vandendriessche, C., Glaveanu, V. \& Lubart, T. (2017). Engineering students' use of creativity and development tools in conceptual product design: what, when and how? Thinking Skills and Creativity, 24, 104-117.

Bowers, M. R., Hall, J. R. \& Srinivasan, M. M. (2017). Organizational culture and leadership style: the missing combination for selecting the right leader for effective crisis management. Business Horizons, 60(4), 551563.

Brockner, J. \& James, E. H. (2008). Toward an understanding of when executives see crisis as opportunity. The Journal of Applied Behavioral Science, 44(1), 94-115.

Brooks, B., Curnin, S., Owen, C. \& Boldeman, J. (2019). New human capabilities in emergency and crisis management: from non-technical skills to creativity. Australian Journal of Emergency Management, The, 34(4), 23.

Bundy, J., Pfarrer, M. D., Short, C. E. \& Coombs, W. T. (2017). Crises and crisis management: integration, interpretation, and research development. Journal of Management, 43(6), 1661-1692.

Cengiz, E., Acuner, T. \& Baki, B. (2007). Orgutsel yaraticiligi belirleyen faktorler arasi yapisal iliskiler. Dokuz Eylul Uni. Sosyal Bilimler Dergisi, 9(1), 98-121.

Chang, Y. S., Lin, H. C., Chien, Y. H. \& Yen, W. H. (2018). Effects of creative components and creative behavior on design creativity. Thinking Skills and Creativity, 29, 23-31.

Chen, A. S. Y. \& Hou, Y. H. (2016). The effects of ethical leadership, voice behavior and climates for innovation on creativity: a moderated mediation examination. The Leadership Quarterly, 27(1), 1-13.

Christensen, T., Lægreid, P. \& Rykkja, L. H. (2016). Organizing for crisis management: building governance capacity and legitimacy. Public Administration Review, 76(6), 887-897.

Coombs, W. T. (2007). Attribution theory as a guide for post-crisis communication research. Public Relations Review, 33(2), 135-139.

Danielsson, E. \& Sjostedt-Landen, A. (2020). Leader normativity in crisis management: tales from a school fire. Risk, Hazards and Crisis in Public Policy, 11(2), 139-165.

Dellas, M. \& Gaier, E. L. (1970). Identification of creativity: the individual. Psychological Bulletin, 73(1), 55.

Devlin, E. S. (2007). Crisis management planning and execution. Auerbach Publications.

Dong, Y., Bartol, K. M., Zhang, Z. X. \& Li, C. (2017). Enhancing employee creativity via individual skill development and team knowledge sharing: Influences of dual-focused transformational leadership. Journal of Organizational Behavior, 38(3), 439-458.

Dorcas, O. A. (2017). Entrepreneurial creativity and innovation: a tool for solving economic crisis in Nigeria. Covenant Journal of Entrepreneurship, 1(2), 20-31.

Egan, T. M. (2005). Factors influencing individual creativity in the workplace: an examination of quantitative empirical research. Advances in Developing Human Resources, 7(2), 160-181.

Eisenberger, R. \& Selbst, M. (1994). Does reward increase or decrease creativity? Journal of Personality and Social Psychology, 66(6), 1116.

Ford, C. M. (1996). A theory of individual creative action in multiple social domains. Academy of Management Review, 21(4), 1112-1142.

George, D. (2011). SPSS for windows step by step: a simple study guide and reference, 17.0 update, 10/e. Pearson Education India. 
Ulku, T. \& Bektas, C. (2021). Individual creativity factor in proactive crisis management in micro and small enterprises. Global Journal of Business, Economics and Management: Current Issues. 11(1), 10-26. https://doi.org/10.18844/gjbem.v11i1.4853

Guo, J., Su, Q. \& Zhang, Q. (2017). Individual creativity during the ideation phase of product innovation: an interactional perspective. Creativity and Innovation Management, 26(1), 31-48.

Hutchins, H. M. \& Wang, J. (2008). Organizational crisis management and human resource development: a review of the literature and implications to HRD research and practice. Advances in Developing Human Resources, 10(3), 310-330.

Hyvarinen, J. \& Vos, M. (2015). Developing a conceptual framework for investigating communication supporting community resilience. Societies, 5(3), 583-597.

Ivanus, G. \& Repanovici, A. (2016). SME's innovation strategy for business continuity and crisis management. Transilvania University of Brasov, 9(58), 155-162.

Johansson, C. \& Back, E. (2017). Strategic leadership communication for crisis network coordination. International Journal of Strategic Communication, 11(4), 324-343.

Kash, T. J. \& Darling, J. R. (1998). Crisis management: prevention, diagnosis and intervention. Leadership and Organization Development Journal, 19(4), 179-186.

Li, H., Chen, T. \& Cao, G. (2017). How high-commitment work systems enhance employee creativity: a mediated moderation model. Social Behavior and Personality: An International Journal, 45(9), 1437-1450.

Liu, D., Gong, Y., Zhou, J. \& Huang, J. C. (2017). Human resource systems, employee creativity, and firm innovation: the moderating role of firm ownership. Academy of Management Journal, 60(3), 1164-1188.

Lockwood, N. R. \& SPHR, G. (2005). Crisis management in today's business environment. SHRM Research Quarterly, 4, 1-9.

Lundvall, B. A. (2008). Innovation and creativity-the crisis as opportunity for change. Europe.

Ma, X. \& Jiang, W. (2018). Transformational leadership, transactional leadership, and employee creativity in entrepreneurial firms. The Journal of Applied Behavioral Science, 54(3), 302-324.

Martens, H. M., Feldesz, K. \& Merten, P. (2016). Crisis management in tourism-a literature based approach on the proactive prediction of a crisis and the implementation of prevention measures. Athens Journal of Tourism, 3(2), 89-101.

Mikusova, M. \& Horvathova, P. (2019). Prepared for a crisis? Basic elements of crisis management in an organisation. Economic Research-Ekonomska Istrazivanja, 32(1), 1844-1868.

Mitroff, I. I. (2019). Crisis management: coping with technology. In Technology run amok (pp. 87-105). Cham, Switzerland: Palgrave Macmillan.

Montani, F., Courcy, F. \& Vandenberghe, C. (2017). Innovating under stress: the role of commitment and leadermember exchange. Journal of Business Research, 77, 1-13.

Nizamidou, C., Vouzas, F. \& Gotzamani, K. (2019). Exploring the interrelationship between quality, safety and HR within crisis management framework. The TQM Journal, 31(4).

Oldham, G. R. \& Cummings, A. (1996). Employee creativity: personal and contextual factors at work. Academy of Management Journal, 39(3), 607-634.

Oran, F. C. \& Demir, Y. (2016). Kriz Yonetim Sureci: Turkiye'de Faaliyet Gosteren Ozel Bir Banka Uzerine Inceleme. Pamukkale University Journal of Social Sciences Institute/Pamukkale Universitesi Sosyal Bilimler Enstitusu Dergisi, (24), 181-197.

Parjanen, S. (2012). Experiencing creativity in the organization: from individual creativity to collective creativity. Interdisciplinary Journal of Information, Knowledge and Management, 7, 109-128.

Parsons, W. (1996). Crisis management. Career Development International, 1(5), 26-28.

Pearson, C. M. \& Mitroff, I. I. (1993). From crisis prone to crisis prepared: a framework for crisis management. Academy of Management Perspectives, 7(1), 48-59.

Pearson, C. M. \& Sommer, S. A. (2011). Infusing creativity into crisis management: an essential approach today. Organizational Dynamics, 40(1), 27-33.

Pirola-Merlo, A. \& Mann, L. (2004). The relationship between individual creativity and team creativity: aggregating across people and time. Journal of Organizational Behavior, 25(2), 235-257.

Ponis, S. T. \& Ntalla, A. (2016). Crisis management practices and approaches: insights from major supply chain crises. Procedia Economics and Finance, 39, 668-673. 
Ulku, T. \& Bektas, C. (2021). Individual creativity factor in proactive crisis management in micro and small enterprises. Global Journal of Business, Economics and Management: Current Issues. 11(1), 10-26. https://doi.org/10.18844/gjbem.v11i1.4853

Rhee, Y. W. \& Choi, J. N. (2017). Knowledge management behavior and individual creativity: goal orientations as antecedents and in-group social status as moderating contingency. Journal of Organizational Behavior, 38(6), 813-832.

Ribeiro, N., Duarte, A. P., Filipe, R. \& Torres de Oliveira, R. (2020). How authentic leadership promotes individual creativity: the mediating role of affective commitment. Journal of Leadership and Organizational Studies, $27(2), 189-202$.

Ritchie, B. W. (2004). Chaos, crises and disasters: a strategic approach to crisis management in the tourism industry. Tourism Management, 25(6), 669-683.

Rosso, B. D. (2014). Creativity and constraints: exploring the role of constraints in the creative processes of research and development teams. Organization Studies, 35(4), 551-585.

Roux-Dufort, C. (2007). Is crisis management (only) a management of exceptions? Journal of Contingencies and Crisis Management, 15(2), 105-114.

Roux-Dufort, C. (2016). Delving into the roots of crises. The genealogy of surprise. The Handbook of International Crisis Communication Research, 43, 24.

Saruhan, S. C. \& Ozdemirci, A. (2018). Bilim, felsefe ve metodoloji (5th ed.). Baski, Istanbul: Beta Yayinlari.

Semedo, A. S. D., Coelho, A. F. M. \& Ribeiro, N. M. P. (2016). Effects of authentic leadership, affective commitment and job resourcefulness on employees' creativity and individual performance. Leadership and Organization Development Journal, 37(8).

Shalley, C. E. (1991). Effects of productivity goals, creativity goals, and personal discretion on individual creativity. Journal of Applied Psychology, 76(2), 179.

Simonton, D. K. (2018). Defining creativity: don't we also need to define what is not creative? The Journal of Creative Behavior, 52(1), 80-90.

Soysal, A., Karasoy, H. A. \& Alici, S. (2009). KOBI'lerde Kriz Yonetimi: K. Maras'ta Tekstil Sektorundeki KOBI'lerde Bir Uygulama. Selcuk Universitesi Sosyal Bilimler Enstitusu Dergisi, 21, 431-446.

Sui Pheng, L., Ho, D. K. \& Soon Ann, Y. (1999). Crisis management: a survey of property development firms. Property Management, 17(3), 231-251.

Tagraf, H. \& Arslan, N. T. (2003). Kriz Olusum Sureci ve Kriz Yonetiminde Proaktif Yaklasim. C.U. Iktisadi ve Idari Bilimler Dergisi, 4(1), 149.

Tekin, O. F. (2016). Kriz Yonetimi ve Kamu Yonetimi Icin Onemi. Selcuk Universitesi Sosyal Bilimler Meslek Yuksek Okulu Dergisi, 18(2), 119-135.

Tierney, P. \& Farmer, S. M. (2002). Creative self-efficacy: its potential antecedents and relationship to creative performance. Academy of Management Journal, 45(6), 1137-1148.

Tugcu, S. (2004). Kriz Yonetiminde Liderlik Kavraminin onemi. Selcuk Universitesi lletisim Fakultesi Akademik Dergisi, 3(2), 16-22.

Vardarlier, P. (2016). Strategic approach to human resources management during crisis. Procedia-Social and Behavioral Sciences, 235(2), 463-472.

Verma, P. \& Rao, M. K. (2016). Organisational performance as a function of creativity components and innovation capability: an Indian perspective. International Journal of Business Performance Management, 17(1), 44-64.

Webb, G. R. \& Chevreau, F. R. (2006). Planning to improvise: the importance of creativity and flexibility in crisis response. International Journal of Emergency Management, 3(1), 66-72.

West, M. A. (1990). The social psychology of innovation in groups. In M. A. West \& J. L. Farr (Eds.), Innovation and creativity at work: psychological and organizational strategies (pp. 309-333). Hoboken, NJ: John Wiley \& Sons.

Widera, A., Fonio, C., Lechtenberg, S. \& Hellingrath, B. (2018). Measuring innovations in crisis management. In 15th International Conference on Information Systems for Crisis Response and Management, Rochester, NY.

Williams, T. A., Gruber, D. A., Sutcliffe, K. M., Shepherd, D. A. \& Zhao, E. Y. (2017). Organizational response to adversity: fusing crisis management and resilience research streams. Academy of Management Annals, 11(2), 733-769. 
Wobodo, C. C. \& Oparanma, A. O. (2019). Crisis management and corporate resilience of multinational oil and gas companies in Rivers State: a theoretical perspective. American Journal of Humanities and Social Sciences Research, 3(5), 7-14.

Wooten, L. P. \& James, E. H. (2008). Linking crisis management and leadership competencies: the role of human resource development. Advances in Developing Human Resources, 10(3), 352-379.

Zhou, J. (2003). When the presence of creative coworkers is related to creativity: role of supervisor close monitoring, developmental feedback, and creative personality. Journal of Applied Psychology, 88(3), 413.

Zhou, J. \& George, J. M. (2001). When job dissatisfaction leads to creativity: encouraging the expression of voice. Academy of Management Journal, 44(4), 682-696.

Zhou, J. \& Shalley, C. E. (2003). Research on employee creativity: a critical review and directions for future research. In Research in personnel and human resources management (pp. 165-217). Bingley, UK: Emerald Group Publishing Limited. 